\title{
S100A10 Gene
}

National Cancer Institute

\section{Source}

National Cancer Institute. S100A10 Gene. NCI Thesaurus. Code C105414.

This gene plays a role in cell cycle progression and cell differentiation. 